\title{
The effect of the peroxisome proliferator ciprofibrate on the gastric mucosa and particularly the gastrin cell
}

\section{H L Waldum, I M Kvetnoi, R Sylte, B Schulze, T C Martinsen and A K Sandvik}

\author{
Laboratory of Endocrinology, Gastroenterology and Oncology, Department of Medicine, \\ University Hospital of Trondheim, Trondheim, Norway and Department of Physiology and \\ Biomedical Engineering, Norwegian University of Science and Technology, Trondheim, Norway \\ (Requests for offprints should be addressed to H L Waldum, Department of Medicine, \\ University Hospital of Trondheim, N-7006 Trondheim, Norway)
}

\begin{abstract}
The peroxisome proliferator ciprofibrate induces hypergastrinemia without inhibiting acid secretion. The present study was carried out to assess the effect of ciprofibrate on serum gastrin and gastrin (G) cells in different strains of rats and to compare the effect of ciprofibrate with other lipid-reducing agents (lovastatin and simvastatin) which have a different mechanism of action.

Serum gastrin was determined by a radioimmunoassay method, $G$ cell density by histomorphometry after immunostaining for $G$ cells, and gastrin, somatostatin and histidine decarboxylase (HDC) mRNA abundance by Northern blot analysis.

Ciprofibrate $(100 \mathrm{mg} / \mathrm{kg} /$ day for three weeks $)$ induced a marked hypergastrinemia $(P<0 \cdot 01)$ in male and female Fischer rats as well as in female
\end{abstract}

Wistar rats. Simvastatin and lovastatin did not affect serum gastrin. Antral $\mathrm{G}$ cell density increased significantly in female Wistar rats $(P<0.05)$ and non-significantly in the other rats after ciprofibrate. Both gastrin and somatostatin mRNA abundance in antral mucosa increased markedly and significantly $(P<0 \cdot 01)$ after ciprofibrate treatment.

The present study shows that the peroxisome proliferator ciprofibrate induces hypergastrinemia secondary to an increased storage and synthesis of antral gastrin. Since somatostatin mRNA abundance also increased, the present study suggests that ciprofibrate and possibly other peroxisome proliferators in sufficient concentrations have a stimulatory effect on endocrine cells.

Fournal of Molecular Endocrinology (1998) 20, 111-117

\section{INTRODUCTION}

It has been known for some years that the so-called peroxisome proliferators induce tumors in the oxyntic mucosa originating from the enterochromaffin-like (ECL) cells (Spencer et al. 1989), and that these tumors are due to hypergastrinemia (Eason et al. 1988b) like those occurring after long-term use of potent inhibitors of acid secretion (Havu 1986). Previously, it was claimed that peroxisome proliferators also reduced gastric acidity, and thus that the mechanism for hypergastrinemia was similar to that after use of proton pump inhibitors (Havu 1986) or histamine $2\left(\mathrm{H}_{2}\right)$ blockers (Poynter et al. 1985). However, the slight reduction in gastric acidity by peroxisome proliferators (Eason et al. 1988a) was much less than that seen during the use of proton pump inhibitors
(Havu 1986). Recently, using a new method for the determination of gastric acidity in the rat (gastric intubation with a pediatric $\mathrm{pH}$ electrode) we showed that the peroxisome proliferator ciprofibrate induced hypergastrinemia without reducing gastric acidity at all (Martinsen et al. 1996). On the contrary, ciprofibrate in high doses decreased gastric $\mathrm{pH}$, probably secondary to the hypergastrinemia induced by ciprofibrate (Martinsen et al. 1996). Since the peroxisome proliferators accordingly seem to have a direct effect on the gastrin $(\mathrm{G})$ cell, the present study was carried out to assess the effect of ciprofibrate on $G$ cell proliferation and gastrin mRNA expression. Furthermore, the effects on somatostatin mRNA abundance in the antral D cell, a cell functionally and anatomically closely connected to the $G$ cell, were also studied. Moreover, the effects on gene expression of the 
oxyntic mucosal D cell and ECL cell, both being neuroendocrine cells of the closed type, were studied (somatostatin mRNA and histidine decarboxylase mRNA respectively). Finally, the effects on different strains of rats as well as rats of different sex were studied as was the effect of the cholesterol reducing agents lovastatin and simvastatin.

\section{MATERIALS AND METHODS}

\section{Test substances}

Ciprofibrate (2-[4(6-2.2 dichlorocyclopropyl) phenoloxyl]-2-methyl propanoic acid), (Modalim, Sanofi/Winthorp, Alnwick, UK), lovastatin (Mevacor MSD, Whitehouse Station, NJ, USA), and simvastatin (Zocor, MSD) were dissolved in sterile water. Sterile water was used in the placebo group.

\section{Animals and animal management}

Male and female Fischer rats $(250 \mathrm{~g})$ and female Wistar rats $(250 \mathrm{~g})$ (Møllegård Breeding Center, Skensved, Denmark), were housed in wirebottomed cages at $20{ }^{\circ} \mathrm{C}$ with a relative humidity of $40-45 \%$ and a 12-h light/darkness cycle. The Rat and Mouse Diet (B \& K Universal Ltd, Hull, UK) and tap water were provided ad libitum. The study was approved by the Animal Welfare Committee of the University Hospital of Trondheim.

\section{Treatment procedures}

The drugs were dissolved in $1 \mathrm{ml}$ sterile water and administered by gastric intubation in the morning each day for three weeks. Ten male and ten female Fischer as well as ten female Wistar rats were given ciprofibrate $(100 \mathrm{mg} / \mathrm{kg} /$ day $)$ while corresponding groups were given sterile water serving as control. Ten male Fischer rats were given lovastatin $(60 \mathrm{mg} / \mathrm{kg} /$ day $)$ for three weeks and another ten male Fischer rats received simvastatin $(50 \mathrm{mg} / \mathrm{kg} /$ day) for the same time period. Blood was taken from the femoral vein by vein puncture before the start of the study and on the last day of the study two hours after the last drug dose. Serum gastrin was determined by a previously described radioimmunoassay using 1,3,4,6-tetra-3 $\alpha$-6 $\alpha$-diphenyl glycouracil (Iodo-gen, Pierce, Rockford, IL, USA) to oxidise ${ }^{125} \mathrm{I}^{-}$and gel chromatography followed by ion exchange chromatography to purify ${ }^{125} \mathrm{I}-$ gastrin (Kleveland et al. 1985). Antibody directed towards the C-terminal active site of gastrin (antibody 4562 donated by Professor J Rehfeld, Copenhagen, Denmark) was used, and free and bound ${ }^{125} \mathrm{I}$-gastrin were separated by double antibody precipitation (Kleveland et al. 1985). The animals were killed by decapitation and the stomach immediately removed, opened at the lesser curvature, rinsed in saline and biopsies were taken from the oxyntic and antral mucosa and fixed in $4 \%$ formalin and Bouin's fixative. Wedge-shaped fullthickness samples for RNA extraction were taken from both oxyntic and antral mucosa. Tissue was homogenized for RNA extraction as described below. The homogenates were immediately frozen and kept at $-80{ }^{\circ} \mathrm{C}$ until further processing.

\section{Preparation of tissue specimens}

Only antral tissue from ciprofibrate-treated animals and controls was studied histologically.

For microscopic examination tissue specimens fixed in Bouin's fixative were embedded in paraffin. The specimens were cut at $5 \mu \mathrm{m}$ (Leica 2055 Autocut) and stained by hematoxylin-erythrosin for general histological examination.

Antral specimens were stained for $G$ cells using primary rabbit antibody to human gastrin 17-34 (Dako, Copenhagen, Denmark) and visualized by the avidin-biotin complex (ABC) method. In short, the paraffin-embedded specimens were dewaxed, rehydrated and treated with $3 \% \mathrm{H}_{2} \mathrm{O}_{2}$ in methanol for $10 \mathrm{~min}$ to block endogenous peroxidase activity. Then the sections were washed in $0 \cdot 1 \mathrm{M}$ phosphatebuffered saline (PBS) ( $\mathrm{pH}$ 7.3) with Triton-X $(0 \cdot 25 \%)$ and incubated in $10 \%$ normal rabbit serum for $30 \mathrm{~min}$ to reduce non-specific antibody binding. Thereafter, the sections were incubated with a gastrin antibody at a dilution of $1: 1200$ at $4{ }^{\circ} \mathrm{C}$ overnight followed by washing in PBS for $10 \mathrm{~min}$. The antibody binding was visualized with the help of Vectastain $\mathrm{ABC}$ kit and AEC substrate kit (Vector, Burlingame, CA, USA).

Nucleated cells with gastrin-positive cytoplasmic granules were counted in five visual fields (each $0.392 \mathrm{~mm}^{2}$ ) at a magnification of 400 (Nicon Optiphot-2). At least three sections from each specimen were counted. The cell count was expressed as the mean number of $G$ cells per visual field.

\section{Generation of cDNA probes}

Tissue was homogenized using a rotating-knife homogenizer (Ultra-Turrax) in a denaturing buffer $(1 \mathrm{ml} / 100 \mathrm{mg}$ tissue) containing $4 \mathrm{M}$ guanidinium isothiocyanate, $25 \mathrm{mM}$ sodium acetate $\mathrm{pH} 6 \cdot 0$, and $0 \cdot 84 \%(\mathrm{v} / \mathrm{v}) \quad \beta$-mercaptoethanol. Tissue was taken from rat cerebral cortex, antral mucosa and rat fetal liver for the generation of somatostatin, gastrin and 
TABLE 1. The effect of ciprofibrate, lovastatin and simvastatin on serum gastrin concentrations in rats of different strain and sex. Values are means \pm S.E.M. $(n=10$ in each group)

\begin{tabular}{|c|c|c|c|}
\hline & \multirow[b]{2}{*}{ Treatment } & \multicolumn{2}{|c|}{ Serum gastrin $(\mathrm{pM})$} \\
\hline & & $\begin{array}{l}\text { Before drug } \\
\text { administration }\end{array}$ & $\begin{array}{l}\text { After drug } \\
\text { administration }\end{array}$ \\
\hline \multicolumn{4}{|l|}{ Rats } \\
\hline \multirow[t]{4}{*}{ Male Fischer } & Control & $75 \cdot 1 \pm 4$ & $73 \pm 5$ \\
\hline & Ciprofibrate $(100 \mathrm{mg} / \mathrm{kg} /$ day $)$ & $67 \pm 5$ & $331 \pm 72$ \\
\hline & Lovastatin $(60 \mathrm{mg} / \mathrm{kg} /$ day $)$ & $72 \pm 5$ & $72 \pm 4$ \\
\hline & Simvastatin $(50 \mathrm{mg} / \mathrm{kg} /$ day $)$ & $61 \pm 3$ & $64 \pm 6$ \\
\hline \multirow[t]{2}{*}{ Female Fischer } & Control & $50 \pm 7$ & $62 \pm 7$ \\
\hline & Ciprofibrate $(100 \mathrm{mg} / \mathrm{kg} /$ day $)$ & $61 \pm 4$ & $243 \pm 50$ \\
\hline \multirow[t]{2}{*}{ Female Wistar } & Control & $46 \pm 4$ & $36 \pm 5$ \\
\hline & Ciprofibrate $(100 \mathrm{mg} / \mathrm{kg} /$ day $)$ & $53 \pm 7$ & $171 \pm 16$ \\
\hline
\end{tabular}

histidine decarboxylase (HDC) probes respectively. Total RNA $(75 \mu \mathrm{g}$ per reaction) was reversetranscribed with oligo dT primer and AMV reverse transcriptase, and subsequently amplified by PCR with primers corresponding to the 1-18 and 429452 positions of rat somatostatin cDNA (Goodman et al. 1983), -18 to +4 and $325-344$ positions of progastrin cDNA (Fuller et al. 1987), and the 1170-1187 and 1734-1751 positions of HDC cDNA (Joseph et al. 1990). The PCR products were cloned into the pCRII vector from the Invitrogen TA cloning kit (Invitrogen, NU Leek, The Netherlands), and the authenticity of the inserts confirmed by DNA sequencing. Glyceraldehyde-3phosphate dehydrogenase $(\mathrm{GAPDH})$ probe was transcribed from the 71-1053 stretch of a commercially available human GAPDH cDNA (Arcari et al. 1984).

Plasmids were used to generate ${ }^{32} \mathrm{P}$-labeled cDNA probes by transcription with either $\mathrm{T} 7$ or SP6 RNA polymerase using standard protocols. The probes were purified on NICK minicolumns (Pharmacia, Uppsala, Sweden).

\section{Somatostatin, gastrin, HDC and GAPDH mRNA quantification}

Northern blots with total RNA from gastric antrum and corpus were prepared as described previously (Dimaline et al. 1993). Membranes were prehybridized for $4 \mathrm{~h}$ at $68{ }^{\circ} \mathrm{C}$ in $50 \%$ formamide, $5 \times$ sodium chloride-sodium phosphate-EDTA buffer (SSPE), $5 \times$ Denhardt's solution, $0 \cdot 5 \%$ SDS and $200 \mu \mathrm{g} / \mathrm{ml}$ sonicated salmon sperm, and hybridized overnight with $2 \times 10^{6}$ c.p.m. ${ }^{32} \mathrm{P}$-labeled probe. The blots were washed twice for $5 \mathrm{~min}$ in $2 \times \mathrm{SSPE}$ with $0 \cdot 1 \%$ SDS at room temperature, and twice for $20 \mathrm{~min}$ in $0 \cdot 1 \times$ SSPE with $0 \cdot 1 \% \operatorname{SDS}$ at $68{ }^{\circ} \mathrm{C}$. The washed membranes were exposed to a storage phosphor screen for $18 \mathrm{~h}$, and the screen scanned on a Phosphorimager (Molecular Dynamics, Sevenoaks, Kent, UK). Images were quantified using ImageQuant software (Molecular Dynamics). The gastric corpus Northern blots were hybridized with somatostatin, HDC and GAPDH probes, and the antral RNA membranes with somatostatin, gastrin and GAPDH probes. Membranes were sequentially hybridized with the different probes and washed with boiling $0 \cdot 1 \%$ SDS between hybridizations. Estimations of mRNA size were made with reference to $18 \mathrm{~S}$ and $28 \mathrm{~S}$ ribosomal RNA bands. Somatostatin, gastrin and HDC mRNA abundances were corrected for variations in GAPDH mRNA.

\section{Statistics}

Differences between pre- and post-treatment parameters were evaluated by paired $t$-test. $P<0.05$ was regarded as significant.

\section{RESULTS}

Ciprofibrate increased serum gastrin in all male Fischer rats $(P<0 \cdot 01)$ with a fourfold increase in mean gastrin value (Table 1$)$. In the male control rats there was no change in serum gastrin during the study (Table 1). Similarly, ciprofibrate induced hypergastrinemia in all female Fischer rats $(P<0 \cdot 01)$ increasing the mean serum gastrin about fourfold whereas serum gastrin was unchanged in the female control rats (Table 1). Ciprofibrate also induced an increase in serum gastrin in all female Wistar rats $(P<0 \cdot 01)$ with a fourfold increase in mean gastrin (Table 1). Serum gastrin was stable during the study in the control female Wistar rats (Table 1). 
TABLE 2. Antral G cell density in ciprofibrate-treated and control rats of different strain and sex. Values are means \pm S.E.M. ( $n=10$ in each group)

\begin{tabular}{llll} 
& Treatment & & $\begin{array}{l}\text { G cell density } \\
\left(\text { cells per } 0 \cdot 392 \mathrm{~mm}^{2}\right)\end{array}$ \\
\cline { 2 - 2 } $\begin{array}{l}\text { Rats } \\
\text { Male Fischer }\end{array}$ & Control & \\
Female Fischer & Ciprofibrate $(100 \mathrm{mg} / \mathrm{kg} /$ day $)$ & & $38 \pm 4$ \\
& Control & & $20 \pm 2$ \\
Female Wistar & Ciprofibrate $(100 \mathrm{mg} / \mathrm{kg} /$ day $)$ & $32 \pm 3$ \\
& Control & $22 \pm 2$ \\
& Ciprofibrate $(100 \mathrm{mg} / \mathrm{kg} /$ day $)$ & $31 \pm 4$ \\
\hline
\end{tabular}

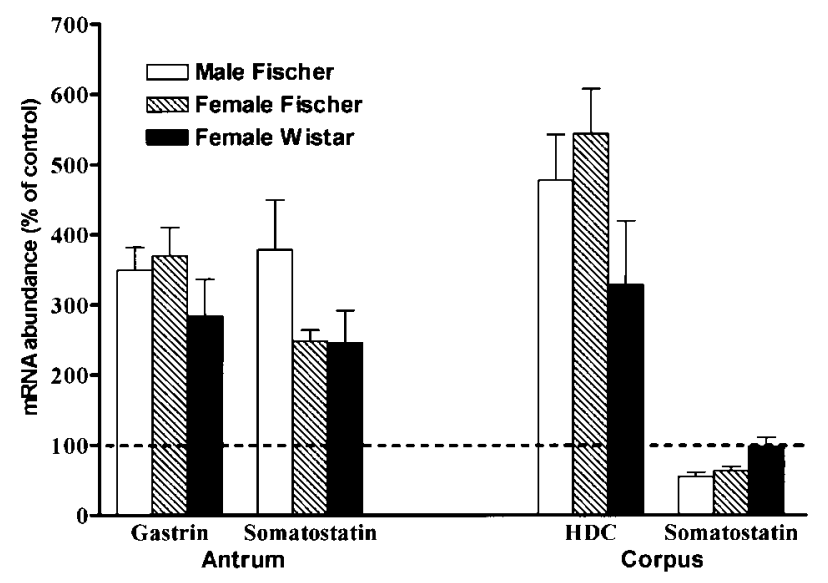

FIGURE 1. Gastrin, somatostatin and histidine decarboxylase (HDC) mRNA abundance in the antrum and corpus of ciprofibrate-treated male and female rats, expressed as a percentage of controls. The different mRNA abundances were corrected for variations in glyceraldehyde-3-phosphate dehydrogenase mRNA.

Neither lovastatin nor simvastatin affected serum gastrin (Table 1).

\section{G cells}

The $\mathrm{G}$ cell density increased significantly $(P<0 \cdot 05)$ in female Wistar rats and non-significantly in the other groups after ciprofibrate (Table 2).

\section{Effects on gene expression in the gastric mucosa}

\section{Antral mucosa}

Ciprofibrate treatment increased gastrin mRNA abundance threefold in male $(P<0 \cdot 01)$ and female $(P<0.01)$ Fischer rats (Fig. 1). Gastrin mRNA abundance also increased almost to the same level in female Wistar rats $(P=0 \cdot 01)$ (Fig. 1). An increase in somatostatin mRNA abundance after the cipro- fibrate treatment was found in the female $(P<0 \cdot 01)$ and male $(P<0.01)$ Fischer rats as well as female Wistar rats $(P<0 \cdot 01)$ (Fig. 1).

\section{Oxyntic mucosa}

A fivefold increase in HDC mRNA was recorded in Fischer rats (both females $(P<0 \cdot 01)$ and males $(P<0 \cdot 01))$ whereas only a threefold non-significant increase was recorded in female Wistar rats (Fig. 1). Somatostatin mRNA abundance was reduced in both male $(P<0 \cdot 01)$ and female $(P<0 \cdot 01)$ Fischer rats whereas it was unaffected in female Wistar rats $(P>0 \cdot 05)$ (Fig. 1).

\section{DISCUSSION}

Female rats have an increased risk compared with male rats of developing ECL-omas after hypergastrinemia secondary to inhibition of gastric acid secretion (Havu 1986). No such sex difference in the frequency of ECL-omas has been reported after long-term use of ciprofibrate (Eason et al. 1988b). In the present study the hypergastrinemia was as pronounced in the male as in the female Fischer rats. Whether the difference in the frequency of ECL-omas between male and female rats secondary to long-term inhibition of acid secretion is due to a different degree of hypergastrinemia between the two sexes, or an increased susceptibility in the ECL cells in the female rats remains to be determined. Nevertheless, ciprofibrate induces a similar hypergastrinemia and a similar frequency of ECL-omas in the two sexes indicating the dominating role of gastrin in this tumorigenesis. Traditionally, Fischer rats have been used in studies showing the development of ECL-omas after use of ciprofibrate (Eason et al. 1988b, Spencer et al. 1989). Due to high gastrin values in controls as well as after long-term ciprofibrate administration (Table 1), these rats may be particularly suitable for demonstrating the toxicity of an agent inducing 
hypergastrinemia. Nevertheless, a marked hypergastrinemia was also recorded after ciprofibrate treatment in female Wistar rats, demonstrating that an effect of ciprofibrate on gastrin release is a general phenomenon not restricted to a particular strain of rat. The fibrates have been used clinically to reduce blood lipids (Illingworth et al. 1982). Therefore, two other drugs with a lipid-reducing effect (lovastatin and simvastatin) (Singer et al. 1988), acting via a different mechanism were studied. Whereas the peroxisome proliferators are believed to reduce blood lipids by stimulating the oxidation of fatty acids, lovastatin and somvastatin reduce hepatic cholesterol synthesis by inhibiting one of the key enzymes in cholesterol synthesis. The latter two drugs had no effect on serum gastrin, supporting the view that the hypergastrinemic effect of ciprofibrate and other fibrates (Eason et al. 1988b) is related to the peroxisome proliferative activity of these compounds.

The release of gastrin from the $\mathrm{G}$ cell is normally stimulated by proteins in the food (Lichtenberger 1982), and inhibited by gastric acidity (Walsh et al. 1975). The vagal nerves also stimulate gastrin release via gastrin releasing peptide (GRP) (Holst et al. 1987) whereas somatostatin inhibits gastrin release (Bloom et al. 1974). We have previously shown that ciprofibrate, contrary to a previous report (Eason et al. 1988a), does not inhibit gastric acid secretion (Martinsen et al. 1996). The discrepancy between the two studies (Eason et al. 1988a, Martinsen et al. 1996) with regard to the effect of ciprofibrate and gastric acidity may be due to differences in study design. Thus, we studied gastric $\mathrm{pH}$ daily during a four-week treatment period with ciprofibrate in rats having normal access to food and water, and found an increase in gastric acidity reaching significance only after several days of ciprofibrate dosing (Martinsen et al. 1996). On the other hand, Eason et al. (1988a) studied the effect of an acute single dose of ciprofibrate on rats fasted for $24 \mathrm{~h}$ by the much more complicated Shay method (Shay et al. 1954). Interestingly, in a more recent study we first found a significant increase in serum gastrin after fourteen days of ciprofibrate treatment (T A Hammer, A K Sandvik \& H L Waldum, unpublished observations). Thus, the apparent discrepancy between the two studies (Eason et al. 1988a, Martinsen et al. 1996) with regard to gastric acidity/secretion is most probably due to different methods and different time of dosing as well as different access to food. Moreover, in spite of administering ciprofibrate only once daily, it induced a sustained hypergastrinemia (Martinsen et al. 1996). The mechanism by which ciprofibrate and other peroxisome proliferators induce hypergastrinemia is unknown. Previously, we found an increase in serum gastrin and gastric acidity in rats having constant access to food (Martinsen et al. 1996). The stomach of such rats contains food continuously. Thus, the food stimulation of gastrin release in these rats was probably about maximal (Martinsen et al. 1996), suggesting that the peroxisome proliferator ciprofibrate induces hypergastrinemia via another mechanism. On the other hand, due to the acidity of the stomach content after ciprofibrate administration (Martinsen et al. 1996), there is a continuous restraint on gastrin release (Walsh et al. 1975). How gastric acid inhibits gastrin release is not completely known. $\mathrm{H}^{+}$ could affect gastrin release via an $\mathrm{H}^{+}$receptor on the luminal side of the $G$ or somatostatin-producing $D$ cell, or more indirectly by reducing the ability of gastrin-releasing compounds to pass through the $G$ cell membrane (Lichtenberger et al. 1982). If ciprofibrate as well as other peroxisome proliferators induce gastrin release by interfering with a membrane protein on the luminal side of the $G$ or $D$ cell, a rather firm or irreversible binding must be postulated since the hypergastrinemia is sustained and stable with a once-daily dose (Martinsen et al. 1996). Whether the peroxisome proliferators release gastrin by a mechanism involving the luminal membrane of the $G$ or $D$ cell or whether they reach these cells via the blood, could have been settled by studying isolated vascularly perfused rat stomachs (Waldum et al. 1991). In a preliminary study we did not find any immediate effect on gastrin release of the peroxisome proliferator clofibrate when it was added to the arterial side of the vascularly perfused rat stomach (K Iwaza and $\mathrm{H} \mathrm{L}$ Waldum, unpublished results). However, very recently we found that the hypergastrinemic effect of ciprofibrate started gradually over a period of some days (T A Hammer, A K Sandvik \& H L Waldum, unpublished observations). Therefore, acute models may not be suitable for studying the effect of ciprofibrate and peroxisome proliferators on gastric acidity/acid secretion.

In the present study there was a significant increase in $\mathrm{G}$ cell density in female Wistar rats and a non-significant rise in the other ciprofibrate-treated rats. Thus, ciprofibrate not only induces an increased release of gastrin as shown by an increase in blood concentration, but also an increase in the density of $G$ cells, suggesting an increase in gastrin synthesis, in agreement with the greatly elevated gastrin mRNA abundance found in the ciprofibratetreated rats. Interestingly, ciprofibrate also increased somatostatin mRNA abundance in the antral mucosa. A concomitant increase in somatostatin and gastrin mRNA abundance in the antral 
mucosa has not, to our knowledge, been reported previously since there seems to exist a reciprocal relationship between the activity of the antral $G$ and $\mathrm{D}$ cells (Wu et al. 1991). Whether ciprofibrate has a direct effect on both cells or the effect on the D cell is secondary to the increase in gastric acidity (Martinsen et al. 1996) provoked by the hypergastrinemic effect, cannot be settled by the present study. It is, however, well known that an increase in gastric acidity stimulates the antral D cell (Holst et al. 1992). Since the degree of increase in mRNA abundance was quite similar for gastrin and somatostatin mRNA in the antral mucosa, a direct effect by ciprofibrate on both the $G$ and $D$ cell seems most probable. It should also be recalled that the acid stimulatory effect of ciprofibrate secondary to the hypergastrinemia was very slight (Martinsen et al. 1996) which makes it rather unlikely that the increase in somatostatin mRNA abundance could be mediated by increased gastric acidity. Therefore, it seems that ciprofibrate has a direct and local effect on endocrine cells of the open type occurring in the stomach. On the other hand, oxyntic mucosal somatostatin mRNA abundance was not increased. This strongly suggests that only endocrine cells of the open type occurring in the upper part of the alimentary tract are exposed to ciprofibrate in concentrations sufficient to induce hormonal release. It should, however, be mentioned that gastrin has a negative tropic effect on the oxyntic D cell (Chen et al. 1992) partly explaining the reduction in somatostatin $\mathrm{mRNA}$ abundance. The marked increase in HDC mRNA in the oxyntic mucosa simply reflects the well-known stimulatory effect of gastrin on the ECL cell (Sandvik et al. 1987) and an increase in HDC mRNA abundance (Sandvik et al. 1994).

In conclusion, the present study shows that the peroxisome proliferator ciprofibrate induces hypergastrinemia in rats of different strains and of different sex, and that this increase in gastrin release is accompanied by an increase in gastrin storage and synthesis. Moreover, ciprofibrate also increases somatostatin mRNA abundance in the antral mucosa suggesting a general stimulatory and releasing effect on endocrine cells exposed to ciprofibrate at a sufficiently high concentration.

\section{ACKNOWLEDGEMENTS}

We acknowledge the superb technical assistance of Anne Kristensen and Kari Havnen. This work was supported by the Norwegian Society for Science and Humanities, and the Norwegian Cancer Society.

\section{REFERENCES}

Arcari P, Martinelli R \& Salvatore F 1984 The complete sequence of a full-length cDNA for human liver glyceraldehyde-3-phosphatase dehydrogenase: evidence for multiple mRNA species. Nucleic Acid Research 12 9179-9189.

Bloom SR, Mortimer CH \& Thorner MO 1974 Inhibition of gastrin and gastric acid secretion by growth hormone release-inhibiting hormone. Lancet i 1106-1109.

Chen D, Uribe A, Håkanson R \& Sundler F 1992 Somatostatin cells in the oxyntic mucosa of hypo- or hypergastrinemic rats. Scandinavian Fournal of Gastroenterology 27 479-482.

Dimaline R, Sandvik AK, Evans D, Forster ER \& Dockray GJ 1993 Food stimulation of histidine decarboxylase messenger RNA in rat gastric fundus. Fournal of Physiology $\mathbf{4 6 5}$ 449-458.

Eason CT, Pattison A, Howells DD \& Bonner FW 1988a The effect of ciprofibrate on gastric secretion in the rat. Fournal of Pharmacology 40 512-513.

Eason CT, Spencer AJ, Pattison A, Howells DD, Henry DC \& Bonner FW $1988 b$ Species variations in gastric toxicity following chronic administration of ciprofibrate to rat, mouse and marmoset. Toxicology and Applied Pharmacology 95 328-338.

Fuller PJ, Stone DL \& Brand SJ 1987 Molecular cloning and sequencing of rat preprogastrin complementary deoxyribonucleic acid. Fournal of Molecular Endocrinology 1 306-310.

Goodman RH, Aron DC \& Roos BA 1983 Rat pre-prosomatostatin. Structure and processing by microsomal membranes. Fournal of Biological Chemistry 258 5570-5573.

Havu N 1986 Enterochromaffin-like cell carcinoids of gastric mucosa in rats after life-long inhibition of gastric secretion. Digestion 35 (Suppl 1) 42-55.

Holst JJ, Knuhtsen S, Ørskov C, Skak-Nielsen T, Poulsen SS \& Nielsen OV 1987 GRP-producing nerves control antral somatostatin and gastrin secretion in pigs. American fournal of Physiology 253 G767-G774.

Holst JJ, Ørskov C \& Seier-Poulsen S 1992 Somatostatin is an essential paracrine link in acid inhibition of gastrin secretion. Digestion 51 95-102.

Illingworth DR, Olsen GD, Cook SF, Sexton GJ, Wendel HA \& Connor WE 1982 Ciprofibrate in therapy of type I hypercholesterolaemia, a double-blind trial. Atherosclerosis $\mathbf{4 4}$ 211-221.

Joseph DR, Sullivan PM, Wang YM, Kozak C, Fenstermacher DA, Behrendsen ME \& Zahnow CA 1990 Characterization and expression of the complementary DNA encoding rat histidine decarboxylase. Proceedings of the National Academy of Sciences of the USA 87 733-737.

Kleveland PM, Haugen SE \& Waldum HL 1985 The preparation of bioactive ${ }^{125} \mathrm{I}$-gastrin, using iodo-gen as oxidizing agent, and the use of this tracer in receptor studies. Scandinavian Fournal of Gastroenterology 20 569-576.

Lichtenberger LM 1982 Importance of food in the regulation of gastrin release and formation. American Fournal of Physiology 243 G429-G441.

Lichtenberger LM, Delansorne MR \& Graziani L 1982 Importance of amino acid uptake and decarboxylation in gastrin release from isolated G cells. Nature 295 698-700.

Martinsen TC, Nesjan N, Rønning K, Sandvik AK \& Waldum HL 1996 The peroxisome proliferator ciprofibrate induces hypergastrinemia without raising gastric $\mathrm{pH}$. Carcinogenesis 17 2153-2155.

Poynter D, Pick CR, Harcourt RA, Selway SAM, Ainge G \& Harman IW 1985 Association of long lasting unsurmountable histamine $\mathrm{H}_{2}$ blockade and gastric carcinoid tumours in the rat. Gut 26 1284-1295. 
Sandvik AK, Waldum HL, Kleveland PM \& Schulze Søgnen B 1987 Gastrin produces an immediate and dose-dependent histamine release preceding acid secretion in the totally isolated, vascularly perfused rat stomach. Scandinavian Fournal of Gastroenterology 22 803-808.

Sandvik AK, Dimaline R, Mårvik R, Brenna E \& Waldum HL 1994 Gastrin regulates histidine decarboxylase activity and mRNA abundance in rat oxyntic mucosa. American fournal of Physiology 267 G254-G258.

Shay H, Sun DCH \& Grienstein M 1954 A quantitative method for measuring spontaneous gastric secretion in the rat. Gastroenterology 26 905-913.

Singer I, Kawka DW \& Huff JW 1988 Lovastatin, an inhibitor of cholesterol synthesis, induces hydroxymethylglutarylcoenzyme A reductase directly on membranes of expanded smooth endoplasmic reticulum in rat hepatocytes. Proceedings of the National Academy of Sciences of the USA $\mathbf{8 5}$ 5264-5268.
Spencer AJ, Barbolt TA, Henry DC, Eason CT, Sauerschell RJ \& Bonner FW 1989 Gastric morphological changes including carcinoid tumours in animals treated with a potent hypolipidaemic agent ciprofibrate. Toxicology and Pathology 17 7-15.

Waldum HL, Kleveland PM \& Sandvik AK 1991 Effects of gastrin on isolated perfused stomach. In The Stomach as an Endocrine Organ, pp 283-296. Erik Fernstrøm Symposium. Eds R Håkanson \& F Sundler. Amsterdam: Elsevier.

Walsh JH, Richardson CT \& Fordtran JS 1975 pH dependence of acid secretion and gastrin release in normal and ulcer subjects. Fournal of Clinical Investigation 55 462-468.

Wu V, Sumii K, Tari A, Sumii M \& Walsh JH 1991 Regulation of rat antral gastrin and somatostatin gene expression during starvation and after refeeding. Gastroenterology 101 1552-1558.

REVISED MANUSCRIPT RECEIVED 26 August 1997 